\title{
Home-Based Learning di Masa Normal Baru: Partisipasi Orang tua Anak Usia Prasekolah
}

\author{
Putu Indah Lestari ${ }^{\circledR}{ }^{\bowtie}$, Elizabeth Prima ${ }^{2}$ \\ Pendidikan Guru Pendidikan Anak Usia Dini, Universitas Dhyana Pura ${ }^{(1,2)}$ \\ DOI: $\underline{10.31004 / o b s e s i . v 6 i 1.1196}$
}

\begin{abstract}
Abstrak
Pandemi Covid-19 telah membuat perubahan tatanan di segala aspek kehidupan termasuk bidang pendidikan. Penelitian ini bertujuan untuk mendeskripsikan proses pembelajaran home-based learning dengan partisipasi orang tua anak usia prasekolah di masa normal baru. Metode penelitian yang digunakan adalah metode analisis deskriptif kualitatif. Teknik pengumpulan data melalui wawancara, kuisioner, dan studi dokumen. Hasil penelitian yaitu pelaksanaan home based-leaning rata-rata selama 2 jam dilakukan secara daring menggunakan perangkat digital. $81,5 \%$ orang tua memberikan kegiatan pembiasaan dalam pelaksanaan home-based learning. Peran ibu lebih mendominasi dalam proses home-based learning. Pelaksanaan home-based learning orang tua tidak hanya menjadi motivator tetapi sekaligus menjadi edukator, fasilitator, dan perpanjangan tangan pihak sekolah. Kendala selama proses home-based learning antara lain: keterbatasan waktu, teknologi, dan pendidikan orang tua. Kelancaran pembelajaran home-based learning memerlukan komunikasi dan kerja sama dari guru serta orang tua.
\end{abstract}

Kata Kunci: home-based learning, partisipasi, orang tua, prasekolah

\begin{abstract}
The Covid-19 pandemic has made changes in all aspects of life, including education. This study aims to describe the home-based learning process with the participation of preschool-aged parents in the new normal. The research method used is descriptive qualitative analysis method. Interview techniques, questionnaires, and document studies. The result of this research is the implementation of home-based leaning for an average of 2 hours done online using digital devices. $81.5 \%$ of parents provide habituation activities in implementing home-based learning. The role of mothers is more dominant in the home-based learning process. The implementation of home-based learning for parents is not only a motivator, but also an educator, facilitator, and additional hands from the school. Constraints during the learning process at home include: limited time, technology, and parental education. The fluency of home-based learning requires communication and cooperation from teachers and parents.
\end{abstract}

Keywords: home-based learning, participation, parents, preschool

Copyright (c) 2021 Putu Indah Lestari, Elizabeth Prima

$\triangle$ Corresponding author :

Email Address : indahlestari@undhirabali.ac.id (Bali, Indonesia)

Received 23 March 2021, Accepted 12 April 2021, Published 14 April 2021 


\section{PENDAHULUAN}

Dirjen World Health Organization (WHO) pada tanggal 11 Maret 2020 telah menetapkan Corona Virus Desease (Covid-19) sebagai pandemi global mengingat kasus ini telah menjangkiti lebih dari tiga juta jiwa dan menyebar ke 148 negara. Pandemi ini tidak hanya berdampak di sektor ekonomi, tetapi juga berdampak di sektor pendidikan yakni ditutupnya sekolah, dampak pada proses pembelajaran, beban pendidikan pada siswa, orang tua, dan guru (Bhamani et al., 2020). Kekhawatiran selama pandemi Covid-19 adalah memelihara pendidikan anak-anak setelah meluasnya penutupan sekolah (Lee et al., 2021). Pemerintah telah membuat peraturan mengenai protokol pencegahan dan kontrol terhadap populasi tertentu di sekolah dan Taman Kanak-kanak antara lain: 1) Sekolah harus memantau kesehatan siswa dengan cermat, mengukur suhu tubuh dua kali sehari, mencatat absen, keberangkatan awal; 2) Pihak sekolah menghindari pelaksanaan pertemuan, rapat dalam skala besar, meningkatkan sarana permbersihan ruang kelas, kantor guru ,perpustakaan, ventilasi, asrama, perpustakaan, pusat kegiatan, kantin, auditorium, toilet serta area kegiatan lainnya, di mana pembersih tangan dan desinfektan tangan harus disediakan; dan 3) Untuk siswa yang ketinggalan kelas karena sakit, pihak otoritas sekolah melakukan pengajaran online dan kelas perbaikan. Menunda ujian bagi siswa yang sakit, ujian susulan harus diatur (Tim Kerja Kementerian Dalam Negeri, 2020).

Anak usia prasekolah adalah anak yang berada pada rentang usia 3-6 tahun. Sedangkan usia prasekolah di Indonesia, umumnya mereka mengikuti program tempat penitipan anak (3 bulan - 5 tahun), kelompok bermain (usia 3 tahun), dan usia 4-6 tahun biasanya mereka mengikuti program taman kanak-kanak (Patmonodewo, 2000). Anak usia prasekolah belajar sambil bermain, belajar melalui komunikasi, interaksi, dan sosialisasi terhadap kelompok lingkungan teman sebaya. Proses pembelajaran untuk anak usia prasekolah dilakukan dengan memenuhi prinsip-prinsip antara lain: 1) Konkret dan sederhana; 2) Pembelajaran menemukan hal-hal baru yang dekat dengan anak; 3) Aktivitas pembelajaran yang menantang; 4) Belajar melalui permainan; 5) Pemberian stimulus dalam proses pembelajaran; dan 6) Belajar tanggung jawab dan mandiri (Mulyasa, 2012). Anak prasekolah masih sangat tergantung pada orang tua dalam proses pendidikan. Pendidikan anak prasekolah memerlukan keterlibatan orang tua dalam mendidik anak sehingga terjadi harmonisasi antara pendidikan di sekolah dan di rumah (Diadha, 2015).

Undang-Undang Nomor 20 Tahun 2003 menyebutkan orang tua dari anak usia wajib belajar berkewajiban memberikan pendidikan dasar bagi anaknya. Keterlibatan orang tua dalam pendidikan dapat diwujudkan dalam berbagai bentuk aktivitas yang dilakukan orang tua. Keterlibatan orang tua akan memberikan keuntungan baik bagi orang tua, anak, maupun sekolah dalam proses pendidikan. Keterlibatan orang tua dalam pendidikan dapat diwujudkan pada berbagai bentuk aktivitas yang dilakukan orang tua baik di rumah atau pun di sekolah (Sistem Pendidikan Nasional, 2003). Partisipasi orang tua dapat diartikan sebagai keterlibatan atau peran serta orang tua dalam mencapai tujuan PAUD, yaitu mengoptimalkan pertumbuhan dan perkembangan anak sehingga nantinya anak dapat bersikap, bertindak, dan bertingkah laku sebagaimana yang diharapkan dalam kelompok sosial tersebut, yakni masyarakat. Partisipasi tidaklah hanya dilihat dari menyekolahkan atau memasukan anak ke dalam lembaga pendidikan usia dini tetapi juga kualitas keterlibatan orang tua dalam ikut mengupayakan pencapaian tujuan pendidikan anak usia dini secara optimal (Rosdiana, 2006).

Panduan penyelenggaraan tahun ajaran 2020/2021 di masa pandemi Covid-19 masih menggunakan sistem pembelajaran daring (dalam jaringan) pada jenjang PAUD hingga SMA akan terus diberlakukan, hal ini berdasarkan keputusan bersama empat kementerian yaitu Kementerian Pendidikan dan Kebudayaan, Kementerian Dalam Negeri, Kementerian Kesehatan, dan Kementerian Agama Republik Indonesia tanggal 15 Juni 2020. Pemerintah membagi menjadi empat zona berdasarkan tingkat kasus Covid-19 yang ada di daerah. Sebanyak 429 kabupaten/kota (64\%) di Indonesia dengan zona kuning, zona oranye dan zona merah tetap melaksanakan kegiatan belajar dari rumah, sementara $6 \%$ daerah berada di zona 
hijau dapat melakukan pembelajaran tatap muka bagi satuan pendidikan dimana dilakukan secara sangat ketat dengan persyaratan berlapis.

Partisipasi orang tua diperlukan ketika terjadi pandemi Covid-19 menyebabkan proses pembelajaran tidak bisa dilangsungkan secara tatap muka, kegiatan belajar dilangsungkan dari rumah. Home-based learning merupakan pendidikan jarak jauh yang dilakukan dimana guru terpisah dengan peserta didik. Peserta didik menggunakan berbagai sumber belajar melalui teknologi komunikasi, informasi, dan media lain guna mengikuti proses pembelajaran dari rumah pembelajarannya. Model pembelajaran yang berbasis di rumah dipandang sebagai cara guru dan orang tua bekerja bersama untuk mendukung pembelajaran anak-anak. Pembelajaran berbasis rumah (home-based learning) merupakan salah satu proses pendidikan jarak jauh dimana siswa belajar di rumah. Sistem pembelajaran berbasis rumah (home-based learning) adalah salah satu peluang pendidikan yang tersedia di luar sekolah. Ini ditujukan untuk anak-anak yang, karena alasan kesehatan, tidak dapat belajar dengan semua anak. Contoh pembelajaran berbasis rumah termasuk membantu anak-anak dengan pekerjaan rumah dan proyek berbasis sekolah, mendukung pembelajaran anak-anak melalui dorongan dan minat, membaca dengan anak-anak, dan mendiskusikan pembelajaran anak-anak. Keterlibatan orang tua juga termasuk kunjungan orang tua ke sekolah untuk mengadvokasi anak-anak, untuk belajar tentang pengalaman pendidikan anak-anak, serta untuk berbagi budaya dan keahlian mereka (Hindin, 2010). (Lilawati, 2020) menemukan peran orang tua terhadap pembelajaran pada masa pendemi meliputi pendampingan dan sebagai motivator. Penelitian ini bertujuan untuk menelaah partisipasi orang tua anak usia prasekolah dalam pelaksanaan home-based learning di masa normal baru.

\section{METODOLOGI}

Metode analisis data yang digunakan dalam peneltian ini adalah metode analisis deskriptif kualitatif. Dalam hal ini penelitian menganalisis partisipasi orang tua mengenai peran mereka dalam mendampingi anak selama pandemi Covid-19. Subjek dalam penelitian ini adalah orang tua yang memiliki anak usia dini dan usia sekolah dasar dengan jumlah 9 orang (3 Ayah, $6 \mathrm{Ibu}$ ) serta orang tua yang memiliki anak prasekolah usia 3 hingga 6 tahun dengan jumlah 65 responden. Selain itu peneliti melakukan wawancara mendalam kepada orang tua yang memiliki anak usia pra sekolah (2 ayah, $6 \mathrm{ibu}$ ) serta kepala sekolah dan guru (4 orang). Lokasi penelitian dilakukan di wilayah Kota Denpasar dan Kabupaten Badung. Teknik pengumpulan data dengan kuisioner dan wawancara dan studi dokumen atau studi pustaka. Penelitian ini menggunakan triangulasi untuk menguji validitas data. Metode triangulasi yang digunakan adalah triangulasi metode dan sumber dengan memeriksa catatan wawancara, catatan lapangan, survei, dan catatan dokumen dari berbagai sumber data. Selanjutnya, data disederhanakan sehingga mudah dibaca dan diinterpretasikan. Analisis ini bertujuan membuat deskripsi secara sistematis, faktual, dan akurat mengenai kajian-kajian partisipasi orang tua dalam home-based learning di masa normal baru.

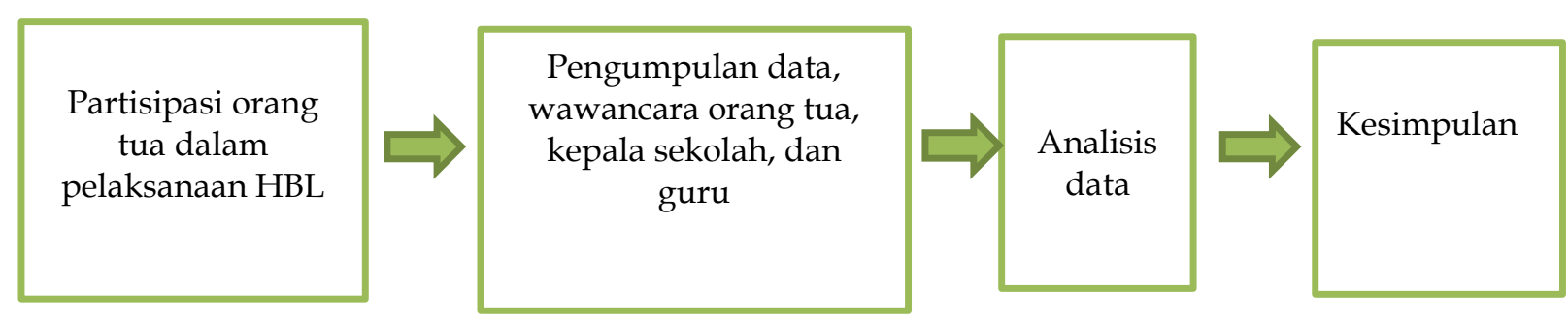

Gambar 1. Alur Penelitian 


\section{HASIL DAN PEMBAHASAN}

\section{Periode Maret 2020 hingga Juni 2020}

Pandemi Covid-19 masuk ke Indonesia di awal bulan Maret 2020, pemerintah melalui Kementerian Pendidikan dan Kebudayaan dengan mengeluarkan Surat Edaran Mendikbud Nomor 3 Tahun 2020 tentang Pencegahan Covid-19 pada Satuan Pendidikan, dan Nomor 36962/MPK.A/HK/2020 tentang Pembelajaran secara Daring dan Bekerja dari Rumah dalam Rangka Pencegahan Penyebaran Corona Virus Disease (Covid-19) dengan memberlakukan pembelajaran secara daring melalui video conference, digital documents, dan sarana daring lainnya dari rumah bagi siswa dan mahasiswa (Kemendikbud, 2020). Sekolah, perkantoran, fasilitas publik tertutup semua aktivitas baik bekerja, mengajar, belajar dilakukan dari rumah. Periode ini disebut masa awal pandemi Covid-19, dimana terjadi perubahan secara cepat di segala sektor termasuk pendidikan. Proses belajar yang semula tatap muka dilakukan secara daring dengan memanfaatkan sarana teknologi. Tri pusat pendidikan yaitu sekolah, pemerintah, dan masyarakat melakukan penyesuaian. Hal senada disampaikan Ibu Suci Kepala Sekolah TK Kumara Jati, menyatakan:

“.....setelah pemerintah memutuskan menutup proses belajar tatap muka digantikan belajar dari rumah dilakukan dari tanggal 16 Maret hingga 22 Maret 2020. Kami di sekolah mengadakan pertemuan dengan komite untuk membahas masalah ini. Kebetulan saat itu menjelang hari raya Nyepi. Kami putuskan selama seminggu kegiatan belajar dilakukan di rumah dengan memberikan lembar kerja pada anak. Informasi ke orang tua disampaikan melalui whattsapp group. Untungnya orang tua mengerti dan memaklumi hal ini. Seminggu, dua minggu kami perlu penyesuaian sambil kami menerima informasi dari dinas....."(kutipan wawancara, Juli 2020)

Program sekolah yang sudah dirancang di awal tahun ajaran tidak dapat berjalan dengan baik. Misalnya kegiatan pentas di akhir tahun ajaran, kegiatan rekreasi, dan program lainnya. Kegiatan pentas seni dilakukan secara virtual. Pak Anton yang memiliki dua anak yang duduk di taman kanak-kanak dan kelompok bermain menjelaskan:

“....kegiatan pentas seni di akhir tahun dilakukan secara virtual. Guru kelas anak saya mengirimkan video berisi 211elah211n yang dihafalkan anak saya. Saya dan istri mengajarkan gerakan-gerakan tarian tersebut. Kemudian kami diminta memvideokan lalu mengirim ke sekolah. Guru akan mengedit video itu, sehingga menjadi video yang menampilkan seluruh siswa. Walaupun lelah, tapi pengalaman itu berkesan bagi anak saya..." (kutipan wawancara, Agustus 2020)

Pada masa awal pandemi, orang tua yang bekerja juga melakukan kegiatan bekerja dari rumah sehingga orang tua dapat menemani anak belajar di rumah. Seperti yang disampaikan Ibu Dwi yang mempunyai anak duduk di kelompok B, menjelaskan:

“....saat itu anak saya duduk di kelas TK-B, kaget adanya virus corona. Kebetulan saya juga bekerja dari rumah. Sehingga saya bisa mendampingi anak saya belajar. Setiap dua minggu sekali saya ke sekolah untuk mengambil lembar kerja yang disiapkan guru di sekolah. Tetapi saya pernah meminta agar lembar kerja dibuatkan softcopy-nya sehingga tidak perlu ke sekolah mengambil. Pihak sekolah sangat kooperatif, tidak hanya itu, uang tamasya yang sudah dibayar di awal tahun ajaran dikembalikan ke orang tua....." (kutipan wawancara, Juli 2020)

Orang tua menjadi guru, pelaksana kegiatan pembelajaran di rumah selama proses belajar dari rumah. Kegiatan pembelajaran disesuaikan dengan program dan kegiatan penugasan yang telah dirancang guru. Sebagai perpanjangtanganan guru, orang tua berperan menyampaikan materi pembelajaran yang telah disiapkan oleh guru (Lilawati, 2020). Pembentukan watak anak dipengaruhi oleh proses pendidikan yang diberikan orang tua kepada anaknya. Hal ini erat kaitannya dengan fungsi akademik orang tua sebagai pendidik pertama dan utama bagi anak. Keterlibatan orang tua merupakan suatu proses dimana orang tua menggunakan segala kemampuan mereka dimana terjadi kerjasama yang antara ayah, ibu, dan anak untuk guna kebermanfaatan anak-anak dan keluarga (Lestari \& Prima, 2020). 


\section{Periode Juli 2020 hingga Desember 2020}

Pandemi Covid-19 menyebabkan proses belajar daring tetap dijalankan hingga memasuki tahun ajaran 2020-2021. Pembelajaran tatap muka sulit dilakukan karena kasus aktif masih tinggi, dikeluarkannya himbauan Menteri Pendidikan dan Kebudayaan untuk melalukan pembelajaran dari rumah. Sesuai dengan surat edaran Menteri Pendidikan dan Kebudayaan Nomor 36982/MPK.A/HK/2020 tentang pembelajaran secara daring dan bekerja dari rumah dalam rangka pencegahan penyebaran corona virus disease (Covid- 19), untuk daerah yang sudah berdampak Covid-19 memberlakukan pembelajaran secara daring dari rumah bagi siswa menggunakan sarana daring. Siswa dapat mengakses sarana belajar daring yang sudah bekerja sama dengan pemerintah seperti Rumah Belajar, Sekolahmu, Zenius, Kelas Pintar dan sekolah online Ruang Guru. Provinsi Bali merupakan provinsi dengan jumlah kasus aktif hingga bulan Desember 2020 terdapat 17.237 kasus dan zona merah (Bali, 2020). Dimana proses pembelajaran tatap muka tidak bisa dilakukan untuk mencegah penularan virus. Penerapan protokol kesehatan yang dilakukan pihak sekolah berupa penyediaan tempat cuci tangan, melalukan pengecekan suhu tubuh, menggunakan masker, dan melakukan pembatasan jarak. Hal senada disampaikan Ibu Eka Kepala Sekolah TK Sinar Cahaya Bangsa

“...tahun ajaran baru ini kami tetap melakukan pembelajaran daring. Anak-anak diberikan tugas mingguan. Setiap Sabtu orang tua mengambil tugas anak ke sekolah, dan menyetorkan tugas sebelumnya. Untuk pertemuan orang tua kami jadwalkan hari dan jamnya sehingga tidak menumpuk di sekolah. Kami menyediakan tempat cuci tangan dan pengecekan suhu tubuh. Setiap orang yang 212ating ke sekolah kami cek suhu tubuhnya. Pembelajaran masih dilakukan menggunakan pertemuan rapat virtual yaitu zoom dengan waktu yang telah disepakati dengan orang tua. Bahkan ada dalam satu kelas guru bisa melakukan zoom sebanyak dua kali dalam sehari pagi dan sore hari. Hal ini dilakukan karena permintaan orang tua, ada orang tua yang bekerja pagi sehingga sore hari baru bisa zoom ..." (kutipan wawancara, September 2020)

Berbeda pada periode awal pandemi, memasuki tahun ajaran baru menjadi tantangan tidak hanya guru di sekolah. Orang tua terkendala menemani anak belajar di rumah karena bekerja. Menurut (Sari et al., 2020) 61\% ibu yang bekerja memiliki waktu yang terbatas untuk menemani anak belajar di rumah. Hal ini disebabkan ibu bertanggunngjawab melakukan pekerjaan-pekerjaan kantor. Akibatnya, anak dititipkan pada kerabat yang ada di rumah. Selajan dengan wawancara Ibu Agung Putri menyatakan:

“....saya mempunyai tiga anak, dimana ketiga anak saya belajar dari rumah. Anak saya yang pertama sudah bisa sendiri. Anak kedua dan ketiga didampingi keponakan saya yang sudah kuliah. Dia yang menemani anak saya belajar, karena saya harus ke kantor..."(kutipan wawancara, September 2020)

Keluarga mempunya tugas yang penting dalam pendidikan anak. Keluarga bertugas melahirkan generasi penerus yang mempunyai budi pekerti baik, cerdas dengan cara menciptakan proses pendidikan berkelanjutan (continues progress) (Jailani, 2014). Kegiatan bermain yang baik bisa terjadi ketika kehadiran anggota keluarga yang lengkap seperti orang tua, saudara, kakek nenek, paman bibi, serta partisipasi orang lain dalam kegiatan bermain anak (Lilawati, 2020).

\section{Partisipasi orang tua dalam home-based leaning}

Pandemi Covid-19 telah membuat perubahan tatanan di segala aspek kehidupan termasuk bidang pendidikan. Hingga bulan Desember 2020 jumlah penduduk yang terkomfirmasi positif Covid-19 berjumlah 650.000 kasus dengan 532 ribu kasus sembuh (82\%). Hampir 12 bulan sekolah menerapkan proses belajar dari rumah dengan sistem daring (dalam jaringan). Sekolah harus menghindari penyelenggaraan pertemuan skala besar, menerapkan protokol kesehatan dengan menyiapkan tempat cuci tangan, memperkuat ventilasi, pembersihan ruang kelas, asrama, perpustakaan, pusat kegiatan, kantin, auditorium, kantor 
guru, toilet dan area aktivitas lainnya, di mana pembersih tangan dan desinfektan tangan harus disediakan.

Penelitian ini menggunakan metode survey yang melibatkan 65 responden yaitu orang tua yang mempunyai anak usia 3-6 tahun dan melakukan proses pembelajaran dari rumah. Adapun responden berprofesi sebagai ibu rumah tangga sebanyak 30 orang $(46,15 \%)$, pedagang sebanyak 5 orang $(7,69 \%)$, karyawan swasta sebanyak 20 orang $(30,77 \%)$, guru/ dosen sebanyak 8 orang (12,31\%) dan ASN sebanyak 2 orang (3,08\%). Selain itu, peneliti melakukan wawancara kepada pihak sekolah, responden untuk mendapat jawaban mendalam tentang pelaksanaan home-based learning selama pandemi Covid-19. Sementara itu jika dilihat dari jenis sekolah dibedakan menjadi dua jenis sekolah yaitu sekolah negeri dan sekolah swasta, sebanyak sebanyak 50 orang $(77 \%)$ responden memiliki anak yang bersekolah di sekolah swasta, baik dikelola swasta murni di bawah yayasan, atau sekolah yang ada di bawah binaan banjar. Sedangkan 15 orang $(23 \%)$ responden adalah memiliki anak yang bersekolah di sekolah negeri.

Penelitian ini membahas partisipasi orang tua anak usia prasekolah dalam pelaksanaan home-based learning di masa normal baru dimulai bulan Mei 2020 hingga Dessember 2020 di Kabupaten Badung dan Kota Denpasar. (Lilawati, 2020) menemukan peran orang tua terhadap pembelajaran pada masa pendemi pada salah satu sekolah di Surabaya meliputi pendampingan dan sebagai motivator. Penelitian ini menemukan bahwa orang tua tidak hanya sebagai motivator, tetapi sekaligus menjadi edukator, fasilitator, dan perpanjangan tangan pihak sekolah. Dalam pendidikan anak, orang tua memiliki peran dalam memberikan dasar-dasar pendidikan sikap dan keterampilan dasar seperti, sopan santun, etika, kasih sayang, rasa aman dasar-dasar. Dasar-dasar pendidikan ditanamkan melalui kebiasaan-kebiasaan hendaknya diberikan oleh keluarga atau orang tua dengan perbuatan bukan hanya dengan nasehat, sebab sikap dasar anak adalah suka meniru (Sutisna, 2007). Salah satu fungsi keluarga adalah fungsi edukasi yaitu fungsi yang berkaitan dengan pendidikan anak yang meliputi mewariskan nilai-nilai dan norma-norma. Artinya pendidikan keluarga berfungsi memberikan warisan nilai-nilai yang berkaitan dengan aspek kepribadian anak memberikan layanan pendidikan, penyediaan dana dan saranya, serta wawasan kepada anak (Jailani, 2014) (Syarbini, 2014). Orang tua berkewajiban memberikan pendidikan dasar bagi anaknya hingga mencapai ketuntasan wajib belajar.

Keterlibatan orang tua dapat diwujudkan dalam berbagai bentuk aktivitas yang dilakukan orang tua baik di rumah atau pun di sekolah (Sistem Pendidikan Nasional, 2003). Partisipasi orang tua dalam pendidikan akan memberikan manfaat baik bagi orang tua, anak, maupun sekolah. Partisipasi orangtua dapat diartikan sebagai keterlibatan atau peran serta orangtua dalam mencapai tujuan PAUD, yaitu mengoptimalkan pertumbuhan dan perkembangan anak sehingga nantinya anak dapat bersikap, bertindak, dan bertingkah laku sebagaimana yang diharapkan dalam kelompok sosial tersebut, yakni masyarakat. Partisipasi tidaklah hanya dilihat dari menyekolahkan atau memasukan anak ke dalam lembaga pendidikan usia dini tetapi juga kualitas keterlibatan orangtua dalam ikut mengupayakan pencapaian tujuan pendidikan anak usia dini secara optimal. partisipasi orangtua ke dalam tiga hal, yaitu: 1) Bantuan orangtua dalam belajar di rumah; 2) Partisipasi dalam menyediakan sarana dan prasarana kelas dan sekolah; dan 3) Komunikasi orangtua-guru tentang pendidikan anak (Rosdiana, 2006).

Dilihat dari sisi gender, jumlah responden didominasi perempuan. Terdapat 10 orang responden berjenis kelamin laki-laki dan sisanya sebanyak 55 orang adalah perempuan. Bentuk keterlibatan orang tua pada perkembangan yaitu keterlibatan orang tua untuk mengembangkan keterampilan yang berguna bagi orang tua, guru, siswa. Peran orang tua selalu peduli terhadap pendidikan anak di sekolah mempengaruhi perkembangan dan prestasi anak. Hasil penelitian yang dilakukan (Amini, 2015) sebanyak 62\% pertemuan orang tua di sekolah khususnya taman kanak-kanak biasanya banyak melibatkan ibu. Ibu memiliki kesempatan yang besar untuk terlibat dalam pendidikan anak di TK, yaitu dengan 
membangun komunikasi secara intensif dengan pihak. Hal senada disampaikan Ibu Indri Respati, orang tua siswa menyatakan:

“...sebagai ibu bertugas mengenal kekurangan dan kelebihan anak saya. Saya memiliki kewajiban mengarahkan anak saya dalam proses belajar. Walaupun suami saya tidak terlibat secara langsung dalam proses pendidikan, kami selalu berdiskusi mengenai pendidikan anak..." (kutipan wawancara, November 2020)

Multi peran dalam kehidupan wanita modern dengan segala aktivitas yang padat harus disiasati dengan mampu membagi waktu untuk karier dan kehidupan pribadi. Wanita di abad 21 menurut Moser dalam (Komalasari, 2017) tidak hanya menjalankan dua peran tetapi tiga peran sekaligus. Ketiga peran tersebut meliputi peran keluarga, peran ekonomi, dan peran sosial. Ketiga peran ini dikenal dengan sebutan triple roles. Peran rumah tangga yaitu peran sebagai pengurus dan pelindung rumah tangga sebagai ibu, istri, maupun anak atau menantu. Peran ekonomi berarti wanita berperan sebagai pencari nafkah, membantu kebutuhan ekonomi keluarga, bahkan pada kondisi tertentu menjadi tulang punggung keluarga. Peran sosio-kultural yaitu peran wanita pada kehidupan sosial sebagai pelaksana adat di keluarga atau lingkungan sekitar dengan baik, agar sesuai dengan norma adat dan budaya yang berlaku di lingkungannya.

Pelaksanaan home based-leaning berlangsung rata-rata selama 2 jam. Pelaksanaan ini di luar waktu belajar tatap muka secara virtual. Orang tua tidak hanya mendampingi anaknya mengerjakan tugas yang diberikan guru maupun belajar dari rumah tetapi juga memberikan pelajaran lain berupa materi lain dan pembiasaan. Sebanyak 70,8\% responden menyatakan memberikan pelajaran tambahan selain materi yang diberikan guru, seperti pengulangan materi pelajaran, aktivitas kreatif, dan kegiatan bermain sambil belajar. Menurut (Khadijah \& Gusman, 2020) model bermain secara daring ada tida yakni model satu arah, model dua arah, dan model multi arah. Model bermain berdasarkan jenis aspek pengembangan kognitif meliputi: 1) Melipat kertas origami; 2) Bermain congklak; 3) Menghitung benda; 4) Menggunting pola; 5) Bermain ular tangga; 6) Mengumpulkan bentuk benda; 7) Bermain teka teki; dan 8) Tebak nama benda dan warna. Permainan aspek bahasa antara lain: 1) Menyanyi; 2) Bercerita; 3) Menirukan suara tertentu; dan 4) Bermain lawan kata sederhana. Permainan aspek motorik antara lain: 1) Petak umpet; 2) Lompat tali; 3) Berjalan jongkok; dan 4) Bermain lari-lari dan berkeliling rumah. Permainan aspek sosial emosional meliputi: 1) Menirukan raut wajah disertai dengan perasaan; 2) Permaianan siapa aku; dan 3) Permainan keakraban bersama orang tua.

Berdasarkan wawancara dengan Ibu Margaretha, seorang guru SD yang memiliki anak duduk di kelompok B menyatakan:

“...Saya mendampingi anak selama belajar dari rumah. Saya membagi waktu saya kapan saya melaksanakan tugas saya mengajar dan kapan saya mendampingi anak saya. Untuk mendampingi anak, saya lakukan setelah saya mengajar SD. Untuk mengisi waktunya sambil menunggu saya mengajar, saya memberikan anak saya untuk menonton program belajar TVRI dari pemerintah setiap jam 8 pagi. Barulah sekitar jam 3 saya baru mengajar anak saya. Saya pun minta izin dan permakluman dari guru TK nya. Biasanya anak-anak belajar 1,5 jam. Jam 3 sampai jam 4.30 sore. Kadang saya lakukan bersamaan saat saya mengajar. Ketika saya mengajar tidak padat, sekalian saya mendampingi anak saya Anak saya pun mandiri melakukan kewajibannya...." (kutipan wawancara, September 2020)

Umar dalam (Safitri et al., 2018) pembentukan kepribadian anak bisa dilakukan dengan sikap pembiasaan. Pembiasaan yang dilakukan berulang-ulang, anak melakukan peniruan di bawah pendampingan dan bimbingan orang tua. Pembiasaan mempengaruhi kemandirian anak. Sikap pembiasaan yang bisa dilakukan di rumah misalnya membiasakan anak bangun pagi, membiasakan anak merapikan mainan setelah bermain, membuang sampah di tempat sampah, anak bertanggungjawab pada dirinya sendiri, dan disiplun. 
Sebanyak $81,5 \%$ responden menyatakan setuju kegiatan pembelajaran untuk anak lebih ditekankan pada kegiatan pembiasaan di sekitar lingkungan rumah. Hal ini sejalan dengan hasil wawancara Ibu Naomi, Guru TK Sinar Cahaya Bangsa menyatakan:

“...kami meminta 215erjasama dari orang tua untuk mendampingi siswa di rumah dalam belajar. Sekolah menyiapkan lembar kegiatan yang dilakukan anak selama satu minggu. Setiap hari Sabtu orang tua ke sekolah untuk menyetorkan tugas minggu ini dan mengambil tugas untuk minggu depan. Kami tidak memaksakan anak-anak mengumpulkan tugasnya hari selesai. Kami menekankan kepada orang tua agar memberikan kegiatan pembiasaan. Misalnya menaruh sepatu di rak sepatu, membantu melipat selimut, beribadah, merapikan mainan sehabis bermain, bahkan saat selesai belajar online pun saya meminta agar anak yang merapikan alat tulisnya.... (kutipan wawancara, Juli 2020)"

Demikian juga dengan hasil wawancara dengan Ibu Nonik Ariyanti, Kepala Sekolah TK Gita Sapta Kumara menjelaskan:

“....kami menyadari tantangan orang tua dalam proses belajar daring ini. Dimana orang tua tidak hanya berkorban waktu, tetapi tenaga dan juga kesabaran. Kami tidak menuntut anak harus pintar calistung. Kami tekankan pada orang tua agar memberikan kegiatan-kegiatan kecapakan hidup (life skiil) misalnya mencuci piring setelah makan, bermain bersama, bangun pagi, berdoa. Bagi kami pihak sekolah, jika anak mampu mencapai capaian pembelajaran adalah bonus..." (kutipan wawancara, November 2020)

Pembiasan sangat efektif dugunakan dalam peminaan sikap anak. Sifat imitating (peniruan) anak usia dini adalah meniru apa yang dilakukan oleh orang-orang yang ada disekitarnya. Oleh sebab itu, sebagai orang tua hendaknya menjadi teladan dan contoh yang terbaik dimata anaknya. Orang tua menginginkan anak tumbuh dengan melakukan kebiasaan baik, terpuji dan menjadi teladan (Cahyaningrum et al., 2017).

Teknologi yang digunakan dalam proses pemnbelajaran berbasis rumah adalah menggunakan platform pertemuan virtual yaitu whatsapp group, google meet, dan zoom meeting. Gambar 2 menunjukkan hasil survey mendapatkan platform whatsapp group (WAG) yang paling banyak digunakan selama proses belajar daring sebesar 83,1\%. WAG banyak digunakan dan tidak memerlulan alat tambahan (seperti computer, printer). Orang tua akan bergabung dalam WAG kelas masing-masing anak kegiatan pembelajaran dipantau melalui WAG. Selain menggunakan WAG, pembelajaran daring juga menggunakan zoom meeting $(40 \%)$, goole classroom $(9,2 \%)$, dan google meet $(7,7 \%)$. Guru tidak hanya memberikan tugas semata kepada siswa, namun kegiatan pemantauan, pendampingan pasti dilakukan guru melalui WAG sehingga anak-anak betul-betul belajar. Sebanyak $81,5 \%$ responden menyatakan memberikan fasilitas seperti gadget, internet untuk mendukung kegiatan belajar dari rumah

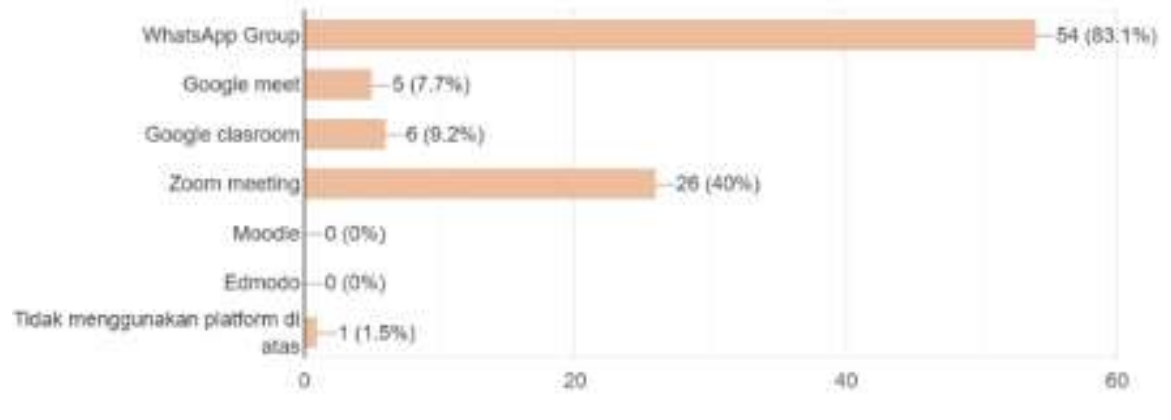

\section{Gambar 2. Platform media belajar daring}

Kelancaran pembelajaran home-based learning memerlukan kerja sama dari guru dan orang tua. Proses komunikasi antara guru, orang tua, dan anak menjadi salah satu penentu keberhasilan kegiatan belajar home-based learning selama pandemi Covid-19. Komunikasi yang efektif adalah satu hal penting yang memengaruhi baik tidaknya proses serta hasil dari 
pembentukan kemandirian anak. Hubungan yang baik antara orang tua dan anak adalah ketika orang tua dapat menyampaikan pesan kepada anak dan anak dapat menerima pesan tersebut sehingga tujuan yang diinginkan orang tua tercapai. Menurut Wiyani dalam (Cahyaningrum et al., 2017) jika komunikasi berjalan lancar, maka dapat menjadikan anak cepat mandiri. Hal ini tentu membantu orang tua dalam memahami setiap perkembangan anak-anaknya. Mengingat, perkembangan anak bisa berbeda-beda di tiap usianya. Dengan komunikasi, orang tua bisa mengetahui seperti apa anak mereka, apa yang mereka suka lakukan, dan tidak suka lakukan.
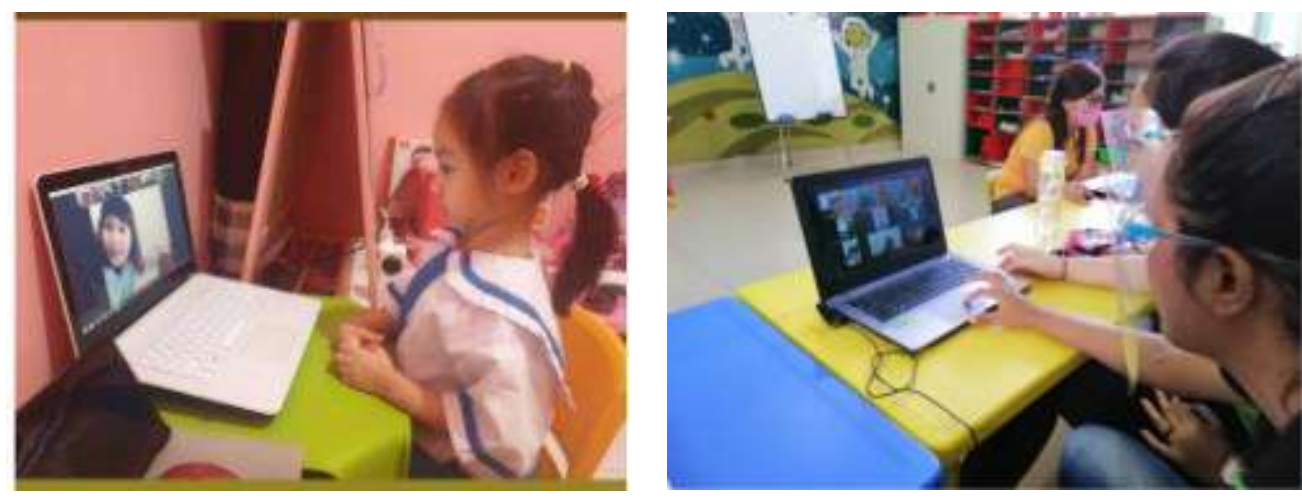

Gambar 3. Kegiatan belajar secara daring

\section{Kendala-kendala yang dihadapi dalam home-based learning}

Pembelajaran berbasis rumah (home-based learning) merupakan salah satu proses pendidikan jarak jauh dimana siswa belajar di rumah. Pendidikan jarak jauh merupakan pendidikan dimana pembelajarannya menggunakan berbagai sumber belajar melalui teknologi komunikasi, informasi, dan media lain. Peserta didiknya terpisah dari pendidik pada pelaksanaan pendidikan jarak jauh (Sistem Pendidikan Nasional, 2003). Sistem pembelajaran berbasis rumah (home-based learning) adalah salah satu peluang pendidikan yang tersedia di luar sekolah. Ini ditujukan untuk anak-anak yang, karena alasan kesehatan, tidak dapat belajar dengan semua anak. Belajar di rumah adalah tanggung jawab besar yang ada pada orang tua. Mereka harus menyediakan persyaratan untuk melakukan sesi pelatihan, termasuk tempat kerja anak dan guru, ketersediaan buku teks, literatur tambahan yang diperlukan, penulisan dan perlengkapan kantor. Orang tua mengawasi pelaksanaan tugas dan rekomendasi guru. Selama belajar di rumah, anak menerima semua pengetahuan baik dari guru, atau orang tua itu sendiri mengajar, atau anak secara mandiri mempelajari mata pelajaran.

Pelaksanaan program pembelajaran berbasis rumah (home-based learning) selama pandemi Covid-19 tidak bisa dipungkuri terdapat berbagai kendala dalam pelaksanaannya. Sebanyak $64,6 \%$ responden menyatakan tidak menargetkan capaian pembelajaran selama proses kegiatan pembelajaran. Hal ini disebabkan hambatan yang dialami orang tua selama proses belajar home-based learning antara lain:

\section{Keterbatasan waktu orang tua dalam menemani proses belajar home-based learning}

Keterbatasan waktu orang tua yang bekerja dalam menemani anak belajar dari rumah selama masa pandemic Covid 19 . Sebanyak 32,3\% orang tua menyatakan waktunya tersita untuk menemani anak belajar dari rumah. Keterbatasan waktu orang tua maupun Surat edaran Nomor 4 Tahun 2020 tentang pelaksanaan kebijakan pendidikan dalam masa darurat guna mencegah penyebaran virus Covid-19, tidak menghalangi momentum keluarga dalam mendampingi anak belajar di rumah.(Wardani \& Ayriza, 2020). Peran orang tua sangatlah penting dalam pelaksanaan home-based learning di masa pandemi Covid-19, sebab orang tua adalah fasilitator menjembatani antara guru dan anak. Orang tua harus selalu berupaya 
semaksimal mungkin untuk membimbing anak ketika belajar di rumah sebab orang tualah menjadi pendidik pertama bagi anak. Kerjasama orang tua sebagai fasilitator bagi anaknya dalam pembelajaran ini bukanlah tercipta secara alami begitu saja, melainkan atas arahan dan instruksi dari pihak sekolah sebelum memulai pembelajaran..

\section{Keterbatasan teknologi (gadget dan internet)}

Tidak dipungkiri pelaksanaan belajar daring banyak memanfaatkan teknologi antara lain gadget (handphone, laptop, komputer, dan internet). Tidak sedikit orang tua memiliki keterbatasan akan teknologi ini. Terlebih orang tua yang mempunyai anak lebih dari satu dan duduk di tingkat sekolah yang berbeda. Kesulitan dalam mengoperasikan gadget juga menjadi kendala yang dihadapi orang tua dalam mendampingi anak belajar di rumah di masa pandemi Covid-19 hal ini disebabkan tidak semua orang tua melek teknologi. Seperti yang disampaikan, Ibu Arie Satikayanti yang mempunyai 4 anak, 2 orang duduk di bangku sekolah dasar dam 2 orang duduk di taman kanak-kanak menjelaskan:

“...saya tidak bisa memantau dengan detail saat belajar dari rumah. Kakak-kakak yang besar saya biarkan mandiri. Mereka masing-masing sudah punya handphone. Untuk anak saya yang masih TK saya gunakan laptop. Suami saya akhirnya berlangganan internet karena jika menggunakan kuota HP cepat habis..." (kutipan wawancara, Agustus 2020)

Komunikasi antara orang tua dan guru sangat dibutuhkan mengingat bahwa tidak semua orang tua fasih megoperasikan gadget (Wardani \& Ayriza, 2020). Selain itu, koneksi dan jaringan internet yang lambat juga menghambat pembelajaran daring, sebab tidak semua wilayah terjangkau oleh layanan internet. Bahkan di beberapa daerah tertentu, peserta didik sampai mencari tempat tinggi tidak terhalang bangunan untuk mendapat sinyal koneksi jaringan internet yang baik.

\section{Keterbatasan pengetahuan orang tua}

Home-based learning tidak bisa maksimal disebabkan latar belakang pengetahuan orang tua mengenai materi pelajaran anak terbatas, terlebih jika orang tua bukan seorang pendidik. Menjadi seorang pendidik tidak hanya mengajar anak dari tidak tahu menjadi tahu, tetapi seni mendidik anak, menamankan penamahan terhadap suatu pelajaran tidak dimiliki orang tua. Orang tua kewalahan dan kurang sabar mendampingi anak belajar walaupun anak masih usia prasekolah. Menyampaikan ilmu kepada anak usia dini tidaklah mudah dan membutuhkan latihan khusus. Hal ini sesuai dengan yang disampaikan Ibu Putri, yang mempunyai 3 orang anak, 2 anak duduk di sekolah dasar dan 1 anak duduk di taman kanak-kanak menjelaskan:

“...ternyata menjadi seorang guru tidak mudah. Walaupun anak saya masih duduk di taman kanak-kanak, saya harus menyiapkan waktu dan terutama saat pelajaran Bahasa Mandarin. Saya meminta anak sulung saya mengajari adiknya. Belum lagi saya harus melatih kesabaran saya karena anak-anak moodian. Harapan saya semoga pandemic ini segera berakhir dan anakanak bisa bersekolah lagi..." (kutipan wawancara, Agustus 2020)

Hal senada disampaikan Bapak Ade yang mempunyai anak yang duduk di kelompok B menyampaikan:

" ...walaupun anak saya masih TK, tetapi saya kesulitan mengajar anak saya. Saya kurang sabar, akibatnya anak saya ngambek dan mogok belajar. Ternyata mengajar anak TK tidak mudah. Kelihatannya gampang. Contohnya saat mengajar berhitung pengurangan, saya tidak mengetahui teknik hitung mundur.." (kutipan wawancara, Oktober 2020)

Reformasi pendidikan berskala besar harus dilakukan setelah krisis Covid-19 berakhir untuk membuat sistem pendidikan lebih fleksibel dan tangguh (Yang et al., 2020). Tri pusat pendidikan yaitu sekolah, pemerintah, dan masyarakat melakukan penyesuaian dalam pelaksanaan pendidikan di masa normal baru dengan memperkaya pengalaman belajar anak melalui kegiatan pembiasaan, bermain sambil belajar yang menyenangkan. 


\section{SIMPULAN}

Pelaksanaan home based-leaning berlangsung rata-rata selama 2 jam dilakukan secara daring menggunakan platform whatsapp group, zoom meeting, dan goole classroom. 81,5\% orang tua memberikan kegiatan pembiasaan dalam pelaksanaan home-based learning. Peran ibu lebih mendominasi dalam proses home-based learning. Pelaksanaan home-based learning orang tua tidak hanya menjadi motivator tetapi sekaligus menjadi edukator, fasilitator, dan perpanjangan tangan pihak sekolah. Kendala selama proses home-based learning antara lain: keterbatasan waktu, teknologi, dan pendidikan orang tua. Kelancaran pembelajaran homebased learning memerlukan komunikasi dan kerja sama dari guru serta orang tua.

\section{UCAPAN TERIMA KASIH}

Ucapan terima kasih disampaikan kepada LPPM Universitas Dhyana Pura, Prodi PGPAUD Fakultas Ekonomika, Bisnis, dan Humaniora atas dukungan serta seluruh responden dalam penelitian ini atas kerjasama yang baik.

\section{DAFTAR PUSTAKA}

Amini, M. (2015). Profil Keterlibatan Orang Tua dalam pendidikan anak usia TK. Jurnal Ilmiah $\begin{array}{llll}\text { VISI PPTK } & \text { PAUDNI, } & \text { 9-20. }\end{array}$ http://journal.unj.ac.id/jurnalfip/index.php/visi/article/view/7/8

Bali, S. C.-19 P. (2020). Perkembangan Akumulatif Kasus Covid-19 di Provinsi Bali.

Bhamani, S., Makhdoom, A. Z., Bharuchi, V., Ali, N., Kaleem, S., \& Ahmed, D. (2020). Home Learning in Times of COVID: Experiences of Parents. Journal of Education and Educational Development, 7(1), 9. https:// doi.org/10.22555/joeed.v7i1.3260

Cahyaningrum, E. S., Sudaryanti, S., \& Purwanto, N. A. (2017). Pengembangan Nilai-Nilai Karakter Anak Usia Dini Melalui Pembiasaan Dan Keteladanan. Jurnal Pendidikan Anak, 6(2), 203-213. https:// doi.org/10.21831/jpa.v6i2.17707

Diadha, R. (2015). Keterlibatan Orang Tua Dalam Pendidikan Anak Usia Dini Di Taman Kanak-Kanak. Edusentris, 2(1), 61. https://doi.org/10.17509/edusentris.v2i1.161

Hindin, A. (2010). Linking home and school: Teacher candiates' beliefs and experiences. The School Community Journal, 20(2), 73-90.

Jailani, M. S. (2014). Teori Pendidikan Keluarga dan Tanggung Jawab Orang Tua dalam $\begin{array}{lllll}\text { Pendidikan Anak Usia Dini. } & 245 .\end{array}$ https:// doi.org/10.21580/nw.2014.8.2.580

Kemendikbud. (2020). Surat Edaran Mendikbud No. 35952/MPK.A/HK/2020 tentang Pembelajaran secara Daring dan Bekerja dari Rumah dalam Rangka Pencegahan Penyebaran Corona Virus Disease (Covid-19). 1-2. https://www.kemdikbud.go.id/main/blog/2020/03/se-mendikbud-pembelajaransecara-daring-dan-bekerja-dari-rumah-untuk-mencegah-penyebaran-covid19

Khadijah, \& Gusman, M. (2020). Pola Kerjasama Guru Dan Orang Tua Mengelola Bermain AUD Selama Masa Pandemi COVID-19. Jurnal Kumara Cendekia, 8(2). https:// doi.org/10.20961/kc.v8i2.41871

Komalasari, Y. (2017). Pengembangan Karier Wanita (Sebuah Konsep Dalam Persepektif Gender). Group Wade.

Lee, S. J., Ward, K. P., Chang, O. D., \& Downing, K. M. (2021). Parenting activities and the transition to home-based education during the COVID-19 pandemic. Children and $\begin{array}{llll}\text { Youth Services } & 105585 .\end{array}$ https:/ / doi.org/10.1016/j.childyouth.2020.105585

Lestari, P. I., \& Prima, E. (2020). Pelibatan Orang Tua Dalam Pendidikan Anak Usia Dini. November, 241-248. 
DOI: 10.31004/obsesi.v6i1.1215

Lilawati, A. (2020). Peran Orang Tua dalam Mendukung Kegiatan Pembelajaran di Rumah pada Masa Pandemi. Jurnal Obsesi: Jurnal Pendidikan Anak Usia Dini, 5(1), 549. https://doi.org/10.31004/obsesi.v5i1.630

Mulyasa, H. E. (2012). Manajemen PAUD. PT. Remaja Rosda Karya.

Patmonodewo, S. (2000). Metode Lagu dalam Pengajaran Pendidikan Agama Islam pada Anak Prasekolah (pp. 18-32). Rineka Cipta bekerjasama dengan Departemen Pendidikan dan Kebudayaan. http://library.walisongo.ac.id/digilib/files/disk1/9/jtptiain-gdl-s12005-sitifaidah-403-Bab2_310-4.pdf

Rosdiana, A. (2006). Partisipasi Orangtua Terhadap Pendidikan Anak Usia Dini : 1(2), 62-72. https://media.neliti.com/media/publications/259930-partisipasi-orangtuaterhadap-pendidikan-89a4e534.pdf

Safitri, N., Setiawati, S., \& Aini, W. (2018). Gambaran Penanaman Kemandirian pada Anak Usia Dini oleh Orang Tua dalam Keluarga. Spektrum: Jurnal Pendidikan Luar Sekolah (PLS), 1(1), 84. https:// doi.org/10.24036/spektrumpls.v1i1.9005

Sari, D. A., Mutmainah, R. N., Yulianingsih, I., Tarihoran, T. A., \& Bahfen, M. (2020). Kesiapan Ibu Bermain Bersama Anak Selama Pandemi Covid-19, "Dirumah Saja." Jurnal Obsesi : Jurnal Pendidikan Anak Usia Dini, 5(1), 476-489. https://doi.org/10.31004/obsesi.v5i1.548

Sutisna, N. (2007). Pendidikan Anak dalam Keluarga. UPI.

Syarbini, A. (2014). Model Pendidikan Karakter dalam Keluarga. PT Elex Media Komputindo. Tim Kerja Kementerian Dalam Negeri. (2020). Pedoman Umum Menghadapi Pandemi Covid19 Bagi Pemerintah Daerah : Pencegahan, Pengendalian, Diagnosis dan Manajemen. Kementerian Dalam Negeri. https://www.kemendagri.go.id/documents/covid19/BUKU_PEDOMAN_COVID-19_KEMENDAGRI.pdf

Sistem Pendidikan Nasional, (2003).

Wardani, A., \& Ayriza, Y. (2020). Analisis Kendala Orang Tua dalam Mendampingi Anak Belajar di Rumah Pada Masa Pandemi Covid-19. Jurnal Obsesi : Jurnal Pendidikan Anak Usia Dini, 5(1), 772. https:// doi.org/10.31004/obsesi.v5i1.705

Yang, H. H., Kwok, L. F., \& Wang, X. (2020). Home-Based Learning During COVID-19 Outbreak: Feedback from Chinese Parents. Teachers College Record. https://www.tcrecord.org/Content.asp?ContentID=23295 